\title{
Model Statement of Criteria and Procedures For Appointment, Promotion in Academic Rank, And Tenure for College and University Librarians
}

The following statement was drafted by the Committee on Academic Status and approved for publication by the Board of Directors of the Association of College and Research Libraries, meeting on June 28, 1973, during their Annual Conference in Las Vegas. It is based upon and elaborates the principles of the association's "Standards for Faculty Status for College and University Librarians" (CRL News, Sept. 1972).

The Board requests that ACRL members send their comments on the Model Statement to Beverly P. Lynch, executive secretary of $A C R L$, at the association's headquarters office. Dr. Lynch will forward these comments to the Committee on Academic Status. The committee will report on the comments it has received at the 1974 Annual Conference in New York.

\section{INTAODUCTION}

This Model Statement of Criteria and Procedures is intended for use within the context of two ACRL policy statements on faculty status for academic librarians. ${ }^{1}$ The objective of this Model Statement is to propose criteria and procedures for appointment, promotion in academic rank and tenure for use in academic libraries which will insure that the Library Faculty, and therefore, the library services, at an institution utilizing these criteria and procedures will be of the highest quality possible, consistent with the goals and resources of the institution. These criteria are intended to be minimal only. These procedures may need to be adjusted in minor detail to conform with existing institutional procedures for other faculty.

\section{Appointment}

Appointment of librarians should follow the same procedures that are established for

1 (a) "Standards for Faculty Status for College and University Librarians." Adopted by the Membership of the Association of College and Research Libraries, Dallas, Texas, June 26, 1971 ;

(b) "Joint Statement on Faculty Status of College and University Librarians." Drafted by a committee of the Association of American Colleges (AAC), the American Association of University Professors (AAUP) and the Association of College and Research Libraries (ACRL) on April 26, 1972. Endorsed by ACRL Membership, Chicago, Illinois, June 26, 1972, and by AAUP Membership, St. Louis, Missouri, April 1973. appointing all faculty. If there are contractual procedures in existence, they must be observed. Any librarian appointed to a college or university Library Faculty should have the appropriate terminal professional degree-for example, a Master's degree or its historical antecedent from a library school accredited by the American Library Association-or its appropriate equivalent. Appointment to any rank should meet the criteria appropriate to that rank.

In order to insure that only candidates of the highest quality are appointed to the $\mathrm{Li}$ brary Faculties of colleges and universities, there should be a committee, representative of the Library Faculty and appropriately selected which should review all candidates for appointment to the Library Faculty and make advisory recommendations to the chief administrative officer of the library.

The terms and conditions of every appointment to the Library Faculty should be stated and confirmed in writing, and copies of all relevant documents, including the official document of appointment, shall be given to the faculty member. Subsequent extensions or modifications of an appointment, and any special understandings or notices incumbent on either party to provide, shall be stated and confirmed in writing and copies shall be given to the faculty member.

Copies of the appointment document, countersigned by the appropriate institutional officer and the faculty member, should be held by both the institution and the individual when an appointment becomes effective.

A model contract is described in Appen$\operatorname{dix}$ A. ${ }^{2}$

\section{Promotion in Academic Rank}

A. General Professional and Scholarly Qualifications of the Library Faculty

The librarian's academic preparation for an appointment to the Library Faculty is established on the basis of the terminal professional degree. The basic quality which must be evident for promotion in academic rank is the ability to perform at a high professional level in areas which contribute to the edu-

${ }^{2}$ All appendixes to this document will be published in the October 1973 issue of CRL News. 
cational and research mission of the institution, such as: reference service, collection development, bibliographic organization and control.

Evidence of this level of performance may be adduced from the judgments of colleagues on the Library Faculty, from members of the academic community outside the library, and/or from professional colleagues outside the academic institution.

Additional evidence for promotion in rank may include:

(1) Contributions to the educational function of the university: for example, teaching, not necessarily in a classroom situation; organization of workshops, institutes or similar meetings; public appearances in the interest of librarianship or information transfer. Evaluation of such activities may be on the basis of the judgment of those who are instructed and by the considered opinion of colleagues.

(2) Contributions to the advancement of the profession: for example, active participation in professional and learned societies as a member, as an officer, as a committee member, or as a committee chairman.

(3) Activities related to inquiry and research: for example, publications, such as in professional and scholarly journals; presentation of papers; reviews of books and other literature; consulting; service as a member of a team of experts, task force, review committee or similar body. Such activities should be judged by professional colleagues on and/ or off the campus on the basis of their contribution to scholarship, the profession of librarianship, and library service.

\section{B. Criteria for Promotion to Specific Ranks}

Promotion to the ranks of assistant professor, associate professor, and professor requires a record of successful fulfillment of criteria at the lower level.

Instructor-Appointments at this rank shall require expectation of successful overall performance and the potential for a promising career in librarianship.

Assistant professor-Promotion to this rank shall require evidence of significant professional contributions to the library and/or to the institution.

Associate professor-Promotion to this rank shall require evidence of substantial professional contributions to the library and to the institution as well as attainment of a high level in bibliographical activities, in research, or in other professional endeavors.

Professor-Promotion to this rank shall require outstanding achievements in bibliographical activities, in research, or in other professional endeavors.
C. Procedures for Promotion to Specific Ranks

1. Candidates from the Library Faculty for promotion in academic rank shall be considered by a standing or ad hoc peer review committee formed in accordance with appropriate institutional regulations. In the absence of specific regulations, such a committee could be selected by the Library Faculty or appointed by the chief administrative officer on the basis of recommendations from the Library Faculty.

2. Recommendations for promotion in academic rank may be made by the appropriate library department head, the appropriate assistant or associate director, or any member of the library faculty.

3. Documentation in support of candidates for promotion in rank shall include evaluations from the appropriate library department head, assistant or associate director. Additional documentation may include letters from colleagues, copies of publications and/or reviews, records of committee activity and the like.

4. Each instructor and assistant professor without tenure shall be formally evaluated and reviewed for promotion or tenure at the same intervals as are applicable to other faculty at the institution holding these ranks.

5. Each assistant professor with tenure and each associate professor shall be reviewed for promotion at intervals and according to procedures of the institution applicable to other faculty members holding these ranks.

6. The ad hoc or standing committee (see C-1) shall transmit its recommendations to the chief administrative officer of the library for all candidates together with all supporting documentation.

7. The chief administrative officer of the library will receive the recommendation of the committee, will make his/her decision, and if this decision is favorable, will transmit the recommendation, with appropriate comments, to the appropriate institutional officer and will so inform the committee and the candidate in writing. If the chief administrative officer of the library does not concur in any particular recommendation, he/she may, after consultation with the committee transmit his/her recommendation, along with that of the committee, to the appropriate institutional officer, and shall so inform the committee and the candidate in writing, indicating the reasons for the action.

8. If a member of the Library Faculty believes there are substantial grounds for disagreement with a denial of promotion, the 
case shall be reviewed according to the appropriate institutional regulations.

\section{Tenure (Continuous Appointment)}

A. Tenure is defined as an institutional commitment to permanent and continuous employment to be terminated only for adequate cause (for example, incompetence; moral turpitude; retirement for reasons of age, mental or physical disability; bona fide financial exigency) and only after due process.

B. The criteria for tenure are closely allied to the criteria for promotion in academic rank. The relationship between tenure and rank should be the same for Library Faculty as for other faculty in the institution.

1. effectiveness of performance as a librarian;

2. scholarly ability as evidenced by the execution of significant research in librarianship or by publication;

3. effectiveness of service to the institution as evidenced by successful service on committees, participation in institutional governance, or by advisement of students and student groups;

4. continuing growth as evidenced by active participation in appropriate professional and scholarly organizations and/or by the ability to handle successfully increased responsibility.

C. A member of the Library Faculty who is a candidate for tenure shall be reviewed according to procedures set forth in established institutional regulations as applied to other faculty on the campus. These procedures will be similar to those described above for promotion in academic rank.

\section{Termination of Appointments 3}

A. Termination of an appointment with continuous tenure, or of a special or probationary appointment before the end of the specified term, may be effected by the institution only for adequate cause.

B. Terminations should follow the due process procedures that are applied to all faculty. If no standard procedures are applied, Appendix B provides a model. ${ }^{4}$

\section{Where termination of an appointment}

${ }^{3}$ Based on the "1972 Recommended Institutional Regulations on Academic Freedom and Tenure." AAUP Bulletin, p.428-33 (Winter 1972)

4All appendixes to this document will be published in the October 1973 issue of $C R L$ News. with continuous tenure, or of a nontenured appointment before the end of a specified term, is based upon bona fide financial exigency of discontinuance of a program or department or instruction, regular procedures will not apply, but faculty members shall be able to have the issues reviewed by the faculty, or by an appropriate faculty committee (such as the faculty's grievance committee), with ultimate review of all controverted issues by the governing board. In every case of financial exigency or discontinuance of a program or a department of instruction, the faculty member concerned will be given notice or severance salary not less than as prescribed. Before terminating an appointment because of the abandonment of a program or department of instruction, the institution will make every effort to place affected faculty members in other suitable positions. If an appointment is terminated before the end of the period of appointment, because of financial exigency, or because of the discontinuance of a program of instruction, the released faculty member's place will not be filled by a replacement within a period of two years, unless the released faculty member has been offered reappointment and a reasonable time within which to accept or decline it.

D. Termination of a tenured appointment, or of a nontenured or special appointment before the end of the period of appointment, for medical reasons, will be based upon clear and convincing medical evidence. The decision to terminate will be reached only after there has been appropriate consultation and the faculty member or his representative has been informed of the basis of the proposed action, and has been afforded the opportunity to present his position and to review the evidence. If the faculty member so requests, the evidence will be reviewed by the Faculty Committee on Academic Freedom and Tenure (or whatever title it may have) before a final decision is made by the governing board on the recommendation of the president of the institution.

\section{Grievance}

General criteria for a grievance procedure:

A. The grievance procedure should be equitable to the institution and to the individual.

B. The grievance procedure should state clearly what is to be done, when, and by whom.

C. The term "grievance" should be clearly defined. Any other terms which could be misunderstood should also be defined. 
D. Grievance procedures should be easy to initjate and accessible to all members of the library faculty.

E. Steps in the grievance procedure should be completed within specified time limits which do not allow either party to delay proceedings unduly. More time should be allowed as the grievance moves to higher levels in the procedure.

F. There should be effective safeguards against reprisal for initiating or participating in a grievance proceeding and against abuse of the procedures by the grievant or by the institution,

G. Excessive reliance on precedent is undesirable.

H. Any grievance procedure in a library must be consistent with applicable institutional regulations and contracts.

A general grievance model for an academic library is attached as Appendix C. A grievance model developed for a specific academic (i.e., college) library is attached as Appen$\operatorname{dix}$ D. ${ }^{5}$

${ }^{5}$ All appendixes to this document will be published in the October 1973 issue of CRL News.

Copies of this article are available from ACRL, 50 E. Huron St., Chicago, IL 60611.

\section{AASL Recruitment Program}

The ALA Executive Board has approved a special AASL recruitment program that might well set the pattern for future divisional membership drives including one for ACRL. Noting that only 5,000 out of some 33,000 school librarians are current members, the experiment includes the following:

- a $\$ 25$ membership fee for one year

- eligibility limited to school librarians who were nonmembers as of April 1973

- membership to give full privileges except that only one division (AASL) can be chosen.

AASL hopes at least to double the school librarian membership in ALA through this drive, while at the same time slowing the recruitment efforts of other groups currently offering to represent school librarians nationally.

\section{ACRL Membership}

June 30, 1973

June 30,1972 .

June 30,1971

The Board of Directors of the Association of College and Research Libraries, having been apprised of the untimely death of Dr. Arthur McAnally on December 1, 1972, has unanimously adopted the following resolution:

WHEREAS; Dr. Arthur McAnally achieved a distinguished career as a library administrator at Knox College, Bradley University, University of New Mexico, University of Illinois, and the University of Oklahoma and

WHEREAS; he served as Professor of Library Science in various library schools where his understanding, his wise counsel, and his clear exposition of the best principles of library procedure helped mold many young people who later became leaders in our profession and

WHEREAS; he gave leadership in library development throughout the country as President of the New Mexico Library Association, the Oklahoma Library Association, and the Southwestern Library Association, and as Chairman of the Oklahoma Council on Libraries, and as consultant and adviser to libraries in South America and abroad, and as a vigorous spokesman for academic and faculty status for college and university librarians and

WHEREAS; he by precept and example set forth the finest ideals of scholarship and service for our entire library profession, therefore

BE IT RESOLVED; That the Association of College and Research Libraries does hereby convey to Mrs. Lucille McAnally and family its deepest sympathy and express its appreciation of his many accomplishments and its indebtedness to him for his significant contributions to our profession.

Done this day the 28th of June, 1973, in meeting assembled in Las Vegas, Nevada. 